\title{
A genomic approach to biomarker discovery in human autoimmune diseases
}

\author{
V Pascual \\ From 5th European Workshop on Immune-Mediated Inflammatory Diseases \\ Sitges-Barcelona, Spain. 1-3 December 2010
}

An integrative evaluation of the complex network of alterations underlying the pathogenesis of autoimmune diseases was until recently difficult to conceive. Technological advances in the past 10 years, however, now permit us to analyze DNA, RNA or protein in patient samples on a genome-wide scale. These techniques are changing the face of clinical research and opening the path for novel approaches to patient care.

The analysis of patient blood transcriptional profiles offers a means to investigate immunological mechanisms relevant to human diseases on a genome-wide scale. In addition, such studies provide a basis for the discovery of clinically-relevant biomarker signatures. We have designed a strategy for microarray analysis that is based on the identification of transcriptional modules formed by genes coordinately expressed in multiple disease datasets. Mapping changes in gene expression at the module-level generates disease-specific transcriptional fingerprints and provides a stable framework for the visualization and functional interpretation of the data.

We have applied this approach to study patients with rheumatic diseases such as Systemic Lupus Erythematosus and Juvenile Arthritis. These studies have provided important insight regarding the pathogenesis of these diseases and have led to the identification of therapeutic targets. This approach is currently being used to identify biomarkers of diagnosis, disease activity and response to treatment. More quantitative and sensitive high throughput RNA profiling methods are starting to be available and will soon permit transcriptome analyses to become routine tests in the clinical setting.

Baylor Institute for Immunology Research, Dallas, TX, USA
Published: 25 November 2010

\section{doi:10.1186/1479-5876-8-S1-I2}

Cite this article as: Pascual: A genomic approach to biomarker discovery in human autoimmune diseases. Journal of Translational Medicine 2010 8(Suppl 1):12.
Submit your next manuscript to BioMed Central and take full advantage of:

- Convenient online submission

- Thorough peer review

- No space constraints or color figure charges

- Immediate publication on acceptance

- Inclusion in PubMed, CAS, Scopus and Google Scholar

- Research which is freely available for redistribution
C Biomed Central 